\title{
Reclassification of Cytophaga aprica (Lewin 1969) Reichenbach 1989 in Flammeovirga gen. nov. as Flammeovirga aprica comb. nov. and of Cytophaga diffluens (ex Stanier 1940; emend. Lewin 1969) Reichenbach 1989 in Persicobacter gen. nov. as Persicobacter diffluens comb. nov.
}

\author{
YASUYOSHI NAKAGAWA, ${ }^{1 *}$ KOEI HAMANA, ${ }^{2}$ TAKESHI SAKANE, ${ }^{3}$ \\ AND KAZUHIDE YAMASATO ${ }^{1} \dagger$ \\ Institute of Applied Microbiology $\neq$, The University of Tokyo, Bunkyo-ku, Tokyo 113, ${ }^{1}$ \\ College of Medical Care and Technology, Gunma University, Maebashi 371, ${ }^{2}$ \\ and Institute for Fermentation, Osaka, Yodogawa-ku, Osaka 532, ${ }^{3}$ Japan
}

\begin{abstract}
Phylogenetically, Cytophaga aprica and Cytophaga diffluens occupy independent positions in the flavobacterbacteroides phylum. Both of these organisms are gram-negative rods that are motile by gliding, chemoorganotrophic, and aerobic, degrade several kinds of biomacromolecules, and inhabit marine environments. Their major isoprenoid quinone is menaquinone 7. The $G+C$ content of the DNA of $C$. aprica is 35 to $37 \mathrm{~mol} \%$, and the $G+C$ content of the DNA of $C$. diffluens is 40 to $42 \mathrm{~mol} \%$. In addition to constituting an independent phylogenetic lineage, each species has a distinctive cellular polyamine constitution. $C$. aprica is characterized by possessing cadaverine as its major polyamine, and $C$. diffluens is characterized by possessing spermidine, in contrast to most species of the genera Cytophaga, Flavobacterium, and Flexibacter and related organisms, which possess homospermidine. Transfer of $C$. aprica to the genus Flammeovirga gen. nov. as Flammeovirga aprica comb. nov. and transfer of $C$. diffluens to the genus Persicobacter gen. nov. as Persicobacter diffluens comb. nov. are proposed.
\end{abstract}

The taxonomic overlap among the genera Cytophaga, Flavobacterium, and Flexibacter and related organisms and the heterogeneity within these genera have been described in several chemotaxonomic and phenotypic investigations $(4,5,9,17$, 26). 16S rRNA cataloging (19) and sequencing (30) have shown that the genera Cytophaga and Flavobacterium, along with the anaerobic genus Bacteroides and other taxa, constitute one phylum in the domain Bacteria (31). 16S rRNA and ribosomal DNA sequencing $(7,14-16,29,32)$ and DNA-rRNA hybridization data $(1,2,24,25)$ have revealed that the genera Cytophaga, Flavobacterium, and Flexibacter are all polyphyletic, and the contradiction between phylogenetic relationships and the present classification means that these genera should be divided into several distinct genera. Vandamme et al. (28) proposed the genus Bergeyella for Weeksella zoohelcum, the genus Chryseobacterium for the Flavobacterium gleum group, and the genus Empedobacter for Flavobacterium breve. Recently, Bernardet et al. (2) emended the genus Flavobacterium to include Flavobacterium, Cytophaga, and Flexibacter species which are characterized by containing menaquinone 6 (MK-6) as the major isoprenoid quinone and by inhabiting soil and freshwater. Nakagawa and Yamasato (16) proposed that the genus Cytophaga should be emended and restricted to two species, Cytophaga hutchinsonii and Cytophaga aurantiaca,

* Corresponding author. Present address: Institute for Fermentation, Osaka, 17-85, Juso-honmachi 2-chome, Yodogawa-ku, Osaka 532, Japan. Phone: 81-6-300-6555. Fax: 81-6-300-6814.

$\uparrow$ Present address: Culture Collection Center, Tokyo University of Agriculture, Setagaya-ku, Tokyo 156, Japan.

$\$$ The present name of the former Institute of Applied Microbiology is Institute of Molecular and Cellular Biosciences. which degrade distinctly crystalline cellulose, and that the genus Marinilabilia should be established for Cytophaga agarovorans and Cytophaga salmonicolor, which are distinguished from other members of the genera Cytophaga, Flavobacterium, and Flexibacter and related genera by being facultative anaerobes, inhabiting marine environments, and containing MK-7 as the major isoprenoid quinone and spermidine as the major polyamine. However, many misnamed cytophagas, flavobacteria, and flexibacteria remain to be reclassified.

The phylogenetic relationships among representative taxa of the flavobacter-bacteroides phylum are shown in Fig. 1. 16S rRNA and ribosomal DNA sequence data were obtained from previously published studies $(3,7,14-16,18,29,30,32)$ and the DNA Data Bank of Japan database. The phylogenetic analysis procedures used in this study have been described previously (16). The reconstructed phylogenetic tree based on 16S rRNA sequences reveals that the species assigned to the genera $\mathrm{Cy}$ tophaga, Flavobacterium, and Flexibacter diverge into several phylogenetic lineages which should be assigned to several independent genera (Fig. 1). The genera Bergeyella, Capnocytophaga, Chryseobacterium, Empedobacter, Flavobacterium, Ornithobacterium, and Weeksella constitute a monophyletic group, which is equivalent to the emended family Flavobacteriaceae (2), as reported previously (7, 14-16). The genera Bacteroides, Marinilabilia, Porphyromonas, and Rikenella belong to the bacteroides subdivision $(16,18,31)$. The genus Sphingobacterium forms an independent cluster $(7,16)$. Flexibacter flexilis, the type species of the genus Flexibacter, is independent of other species. Microscilla marina, the type species of the genus $M i$ croscilla, constitutes an independent phylogenetic lineage. The genera Flexibacter and Microscilla should each be restricted to 


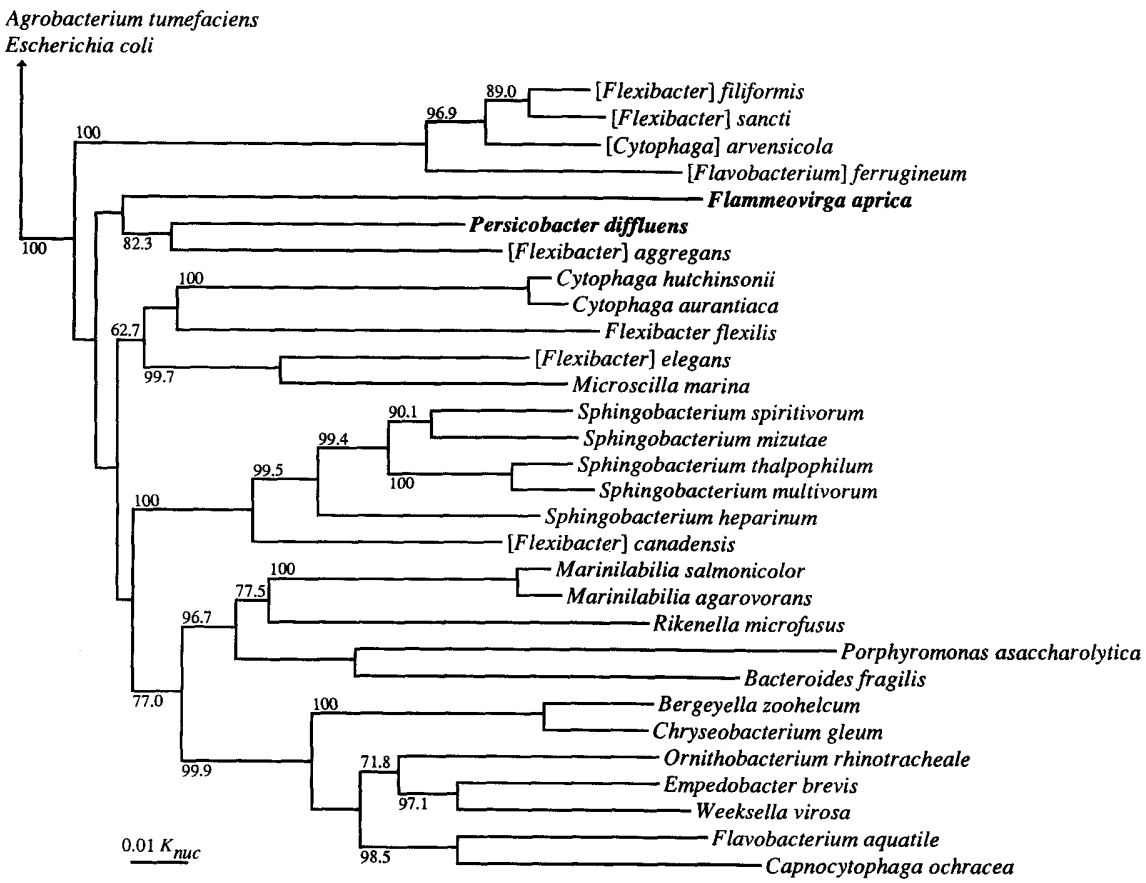

FIG. 1. Phylogenetic tree derived from 16S rRNA sequences for the members of the Flavobacterium-Cytophaga complex and related genera. All of the sequences used are the sequences of the type strains (the strain of Escherichia coli is unknown). The brackets indicate generically misclassified bacteria. Agrobacterium tumefaciens and $E$. coli were used as the root organisms. The software package Clustal V (10) was used to generate similarity values and $K_{\text {nuc }}$ values (13) and to reconstruct a phylogenetic tree by the neighbor-joining method (23). Scale bar $=0.01 K_{\text {nuc }}$ in nucleotide sequences. The lengths of the vertical lines are not significant. The total number of nucleotides compared was 903 after elimination of the positions at which secondary structures varied in the strains (16) and all sites which were not determined in any sequence. The numbers on the branches are the confidence limits (expressed as percentages) estimated by a bootstrap analysis $(6)$ with 1,000 replicates. Confidence limits of less than $60 \%$ are not shown.

the species which are closely related to the respective type species of these genera.

Cytophaga aprica and Cytophaga diffluens occupy distinct positions in this group of bacteria, and both of these taxa are far removed from other previously described genera (Fig. 1). The levels of $16 \mathrm{~S}$ rRNA sequence similarity between $C$. aprica and other species are less than $85.1 \%$, and the levels of 16S rRNA sequence similarity between $C$. diffluens and other species are less than $89.4 \%$ (Table 1 ). Both $C$. aprica and $C$. diffluens are gram-negative rods that are motile by gliding, chemoorganotrophic, and aerobic, degrade several kinds of biomacromolecules, inhabit marine environments, and contain MK-7 as the major isoprenoid quinone (Table 2). In addition to constituting an independent phylogenetic lineage, each of these species has a distinctive cellular polyamine constitution (8). $C$. aprica is characterized by containing cadaverine as its only major polyamine. The other cadaverine-containing species in the group that contains $C$. aprica are Flexibacter maritimus and Cytophaga latercula (8), which are distinguished by containing MK-6 as the major isoprenoid quinone (14). C. diffluens is characterized by possessing spermidine as the major polyamine. The other related species which contain spermidine are Marinilabilia agarovorans, Marinilabilia salmonicolor, and $C y$ tophaga fermentans (8), all of which are facultative anaerobes, and some Bacteroides and Porphyromonas species (8), which are strict anaerobes. On the basis of the facts described above, we propose that $C$. aprica should be transferred to the genus Flammeovirga gen. nov. as Flammeovirga aprica ((Lewin 1969) Reichenbach 1989) comb. nov. and that $C$. diffluens should be transferred to the genus Persicobacter gen. nov. as Persicobacter diffluens ((Stanier 1940; emend. Lewin 1969) Reichenbach 1989) comb. nov. Taxonomic characteristics of the genera Flammeovirga and Persicobacter and allied bacteria are shown in Table 2. The descriptions of the genera Flammeovirga and Persicobacter which are given below are taken from the data of Reichenbach (20) and our own data.

Description of Flammeovirga gen. nov. Flammeovirga (Flam. me.o.vir'ga. L. adj. flammeus, fire colored; L. fem. n. virga, rod; L. fem. n. Flammeovirga, fire-colored rod). Cells are long and flexible rods that are 0.5 to $0.7 \mu \mathrm{m}$ wide and 6 to $30 \mu \mathrm{m}$ long. There is no resting stage. Motile by gliding. Gram negative. Cell mass is orange to reddish orange. Oxidase positive and catalase negative. Strict aerobes with a respiratory type of metabolism. Chemoorganotrophs. All strains of the type species decompose alginate, agar, gelatin, and starch but not crystalline cellulose. Marine organisms. The optimum temperature is 25 to $30^{\circ} \mathrm{C}$. The optimum $\mathrm{pH}$ is around 7 .

The major isoprenoid quinone is MK-7. The major polyamine is cadaverine. The $\mathrm{G}+\mathrm{C}$ content of the DNA is 35 to 37 mol\%. The type species of the genus is Flammeovirga aprica comb. nov. The description of $F$. aprica is the same as that given by Reichenbach (20).

Description of Persicobacter gen. nov. Persicobacter (Per.si. co.bac'ter. Gr. neut. n. persikon, peach; M.L. masc. n. bacter, rod; L. masc. n. Persicobacter, peach rod, because the organism is a peach-colored rod). Cells are slender flexible rods that are $0.5 \mu \mathrm{m}$ wide and 4 to $30 \mu \mathrm{m}$ long. There is no resting stage. Motile by gliding. Gram negative. Cell mass is pink to orange. Oxidase positive and catalase negative. Strict aerobes with a respiratory type of metabolism. Chemoorganotrophs. All 
TABLE 1. 16S rRNA sequence similarity matrix for species of the genera Cytophaga, Flavobacterium, and Flexibacter and the related taxa

\begin{tabular}{|c|c|c|c|c|c|c|c|c|c|c|c|c|c|c|c|c|c|c|c|c|c|c|}
\hline \multirow[b]{2}{*}{ Species $^{a}$} & \multicolumn{22}{|c|}{$\%$ Similarity } \\
\hline & 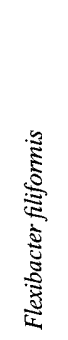 & 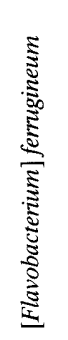 & 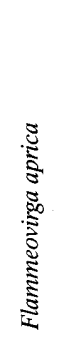 & 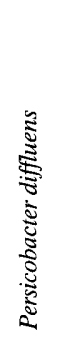 & 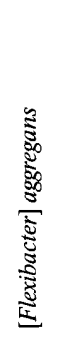 & 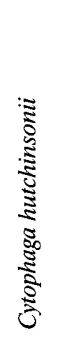 & 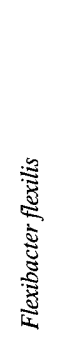 & 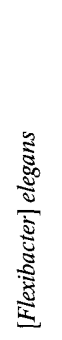 & 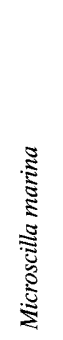 & 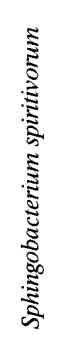 & 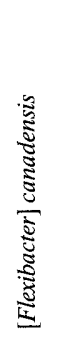 & 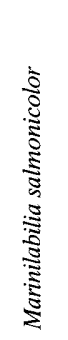 & 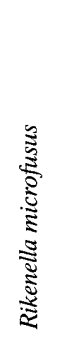 & 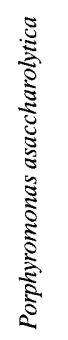 & 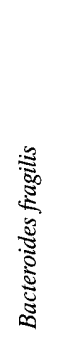 & 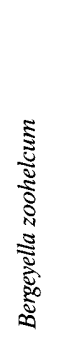 & 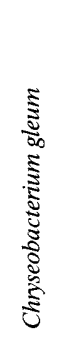 & 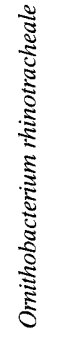 & 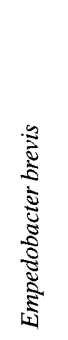 & 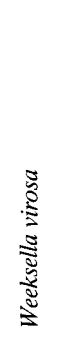 & 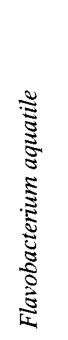 & 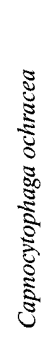 \\
\hline [Flavobacterium] ferrugineum & 92.6 & & & & & & & & & & & & & & & & & & & & & \\
\hline Flammeovirga aprica & 81.2 & 80.1 & & & & & & & & & & & & & & & & & & & & \\
\hline Persicobacter diffluens & 84.7 & 83.7 & 85.1 & & & & & & & & & & & & & & & & & & & \\
\hline [Flexibacter] aggregans & 84.8 & 83.7 & 83.9 & 89.4 & & & & & & & & & & & & & & & & & & \\
\hline Cytophaga hutchinsonii & 83.3 & 81.7 & 83.5 & 86.4 & 85.7 & & & & & & & & & & & & & & & & & \\
\hline Flexibacter flexilis & 82.8 & 80.2 & 82.3 & 86.3 & 84.9 & 86.8 & & & & & & & & & & & & & & & & \\
\hline [Flexibacter] elegans & 84.8 & 82.2 & 83.0 & 87.2 & 87.2 & 85.3 & 86.2 & & & & & & & & & & & & & & & \\
\hline Microscilla marina & 82.8 & 81.0 & 81.6 & 85.7 & 84.9 & 86.6 & 86.3 & 90.7 & & & & & & & & & & & & & & \\
\hline Sphingobacterium spiritivorum & 84.2 & 80.8 & 83.9 & 85.8 & 84.9 & 84.6 & 84.6 & 85.9 & 85.2 & & & & & & & & & & & & & \\
\hline [Flexibacter $]$ canadensis & 85.2 & 82.8 & 81.8 & 86.3 & 87.7 & 86.7 & 85.9 & 85.7 & 87.8 & 90.7 & & & & & & & & & & & & \\
\hline Marinilabilia salmonicolor & 84.8 & 83.0 & 83.0 & 87.4 & 84.8 & 85.1 & 85.1 & 85.4 & 84.3 & 86.5 & 87.5 & & & & & & & & & & & \\
\hline Rikenella microfusus & 80.6 & 79.6 & 82.1 & 84.2 & 83.1 & 83.9 & 83.5 & 84.5 & 83.5 & 86.3 & 86.1 & 88.9 & & & & & & & & & & \\
\hline Porphyromonas asaccharolytica & 80.4 & 80.6 & 80.5 & 80.4 & 78.7 & 80.3 & 79.7 & 83.2 & 82.1 & 80.8 & 82.5 & 84.7 & 83.4 & & & & & & & & & \\
\hline Bacteroides fragilis & 82.4 & 81.1 & 80.0 & 84.5 & 83.0 & 83.0 & 81.1 & 82.2 & 82.3 & 82.3 & 84.2 & 86.8 & 85.1 & 85.6 & & & & & & & & \\
\hline Bergeyella zoohelcum & 81.5 & 80.7 & 80.6 & 84.4 & 83.8 & 83.1 & 83.9 & 85.5 & 84.7 & 84.8 & 84.5 & 85.9 & 85.6 & 81.7 & 83.6 & & & & & & & \\
\hline Chryseobacterium gleum & 83.2 & 82.0 & 80.7 & 85.3 & 83.4 & 83.3 & 83.9 & 85.5 & 85.2 & 84.8 & 84.1 & 86.1 & 85.1 & 81.4 & 83.2 & 96.2 & & & & & & \\
\hline Ornithobacterium rhinotracheale & 82.7 & 83.0 & 82.4 & 84.8 & 84.2 & 84.1 & 83.1 & 83.7 & 83.3 & 84.2 & 84.9 & 86.3 & 85.2 & 81.5 & 81.0 & 89.9 & 90.1 & & & & & \\
\hline Empedobacter brevis & 83.0 & 83.5 & 81.0 & 84.7 & 85.1 & 83.3 & 83.6 & 83.1 & 83.2 & 84.1 & 85.1 & 84.8 & 83.6 & 81.0 & 82.5 & 89.5 & 90.0 & 91.3 & & & & \\
\hline Weeksella virosa & 83.7 & 83.2 & 80.3 & 83.1 & 83.1 & 83.4 & 82.1 & 83.8 & 83.8 & 83.6 & 83.6 & 84.2 & 84.1 & 81.6 & 82.2 & 88.78 & 88.7 & 90.3 & 92.4 & & & \\
\hline Flavobacterium aquatile & 83.5 & 83.3 & 80.6 & 83.1 & 83.5 & 82.6 & 81.5 & 83.6 & 83.0 & 83.0 & 84.2 & 84.2 & 83.9 & 82.1 & 82.6 & 86.3 & 86.8 & 89.5 & 88.7 & 89.5 & & \\
\hline phaga ochracea & 81.5 & 82.6 & 80.4 & 83.0 & 82.2 & 82.1 & 80.3 & 82.2 & 81.7 & 82.5 & 83.8 & 84.6 & 83.3 & 82.8 & 82.1 & 85.5 & 85.6 & 87.3 & 88.5 & 87.9 & 90.5 & \\
\hline Escherichia coli & 77.1 & 77.4 & 77.2 & 79.4 & 79.5 & 78.5 & 77.5 & 79.0 & 78.1 & 76.5 & 78.1 & 77.3 & 77.1 & 74.0 & 75.8 & 76.9 & 77.0 & 75.9 & 78.2 & 77.6 & 76.4 & 75.3 \\
\hline
\end{tabular}

${ }^{a}$ The brackets indicate generically misclassified bacteria.

strains of the type species decompose alginate, agar, gelatin, and starch. Marine organisms. The optimum temperature is 25 to $30^{\circ} \mathrm{C}$. The optimum $\mathrm{pH}$ is around 7 .

The major isoprenoid quinone is MK-7. The major poly- amine is spermidine. The $\mathrm{G}+\mathrm{C}$ content of the DNA is 40 to 42 mol\%. The type species of the genus is Persicobacter diffluens comb. nov. The description of $P$. diffluens is the same as that given by Reichenbach (20).

TABLE 2. Taxonomic characteristics of the genera Flammeovirga and Persicobacter, the emended genera Cytophaga and Flavobacterium, and allied bacteria ${ }^{a}$

\begin{tabular}{|c|c|c|c|c|c|c|c|}
\hline Taxon & Habitat & $\begin{array}{l}\text { Relation to } \\
\text { oxygen }^{b}\end{array}$ & Pigmentation & Sphingolipid & $\begin{array}{c}\mathrm{G}+\mathrm{C} \text { content } \\
(\mathrm{mol} \%)\end{array}$ & Polyamine $^{c}$ & Quinone(s) \\
\hline Flammeovirga & Marine & A & + & $\mathrm{ND}^{d}$ & $35-37$ & Cad & MK-7 \\
\hline Persicobacter & Marine & A & + & ND & $40-42$ & Spd & $\mathrm{MK}-7$ \\
\hline Bergeyella & Parasitic, saprophytic & A & - & - & $35-37$ & ND & MK-6 \\
\hline Capnocytophaga & Parasitic, saprophytic & $\mathrm{F}$ & + & ND & $33-41$ & ND & MK-6 \\
\hline Chryseobacterium & Free-living, parasitic & A & + & - & $33-38$ & Hspd & MK-6 \\
\hline Cytophaga & Soil & A & + & ND & $39-42$ & Hspd & MK-7 \\
\hline Empedobacter & Free-living, parasitic & A & + & - & $31-33$ & Hspd & MK-6 \\
\hline Flavobacterium & Free-living, saprophytic & A & + & - & $32-37$ & Hspd & MK-6 \\
\hline Flexibacter & Soil, freshwater & A & + & ND & $29-48$ & Hspd & MK-6, MK-7 \\
\hline Marinilabilia & Marine & $\mathrm{F}$ & + & ND & $37-41$ & Spd & $\mathrm{MK}-7$ \\
\hline Microscilla & Marine & A & + & ND & $32-44$ & ND & ND \\
\hline Ornithobacterium & Parasitic & $\mathrm{F}$ & - & ND & $37-39$ & ND & MK-6 \\
\hline Riemerella & Parasitic & M & - & ND & $29-35$ & ND & MK-6 \\
\hline Sphingobacterium & Free-living, saprophytic & A & + & + & $39-45$ & Hspd & $\mathrm{MK}-7$ \\
\hline Weeksella & Parasitic, saprophytic & A & - & - & $35-38$ & ND & MK-6 \\
\hline
\end{tabular}

${ }^{a}$ Data from references $8,11,12,14-17,20-22,24,27-29$, and 33 .

${ }^{b}$ A, strict aerobes; F, facultative anaerobes; M, microaerophiles.

${ }^{c}$ Cad, cadaverine; Spd, spermidine; Hspd, homospermidine.

${ }^{d}$ ND, not determined. 
We are grateful to A. Nakagiri (Institute for Fermentation, Osaka) for his advice concerning Latin. Y.N. and K.Y. also thank the American Type Culture Collection (Rockville, Md.), the Deutsche Sammlung von Mikroorganismen und Zellkulturen GmbH (Braunschweig, Germany), the Institute of Molecular and Cellular Biosciences, The University of Tokyo (Tokyo, Japan), the Institute for Fermentation, Osaka (Osaka, Japan), the Japan Collection of Microorganisms (Wako, Japan), the National Collection of Industrial and Marine Bacteria, Ltd. (Aberdeen, United Kingdom), and the National Collection of Type Cultures, Public Health Laboratory Service (London, United Kingdom) for kindly supplying bacterial cultures.

This work was supported in part by Grant-in-Aid for Co-operative Research 03304017 and Grant-in-Aid for Encouragement of Young Scientists 08760313 from the Ministry of Education, Science, Sports and Culture of Japan.

\section{REFERENCES}

1. Bauwens, M., and J. De Ley. 1981. Improvements in the taxonomy of Fla vobacterium by DNA:rRNA hybridizations, p. 27-31. In H. Reichenbach and O. B. Weeks (ed.), The Flavobacterium-Cytophaga group. Verlag Chemie, Weinheim, Germany.

2. Bernardet, J.-F., P. Segers, M. Vancanneyt, F. Berthe, K. Kersters, and P. Vandamme. 1996. Cutting a gordian knot: emended classification and de scription of the genus Flavobacterium, emended description of the family Flavobacteriaceae, and proposal of Flavobacterium hydatis nom. nov. (basonym, Cytophaga aquatilis Strohl and Tait 1978). Int. J. Syst. Bacteriol. 46:128-148.

3. Brosius, J., M. L. Palmer, P. J. Kennedy, and H. F. Noller. 1978. Complete nucleotide sequence of a 16S ribosomal RNA gene from Escherichia coli. Proc. Natl. Acad. Sci. USA 75:4801-4805.

4. Callies, E., and W. Mannheim. 1978. Classification of the Flavobacterium Cytophaga complex on the basis of respiratory quinones and fumarate respiration. Int. J. Syst. Bacteriol. 28:14-19.

5. Christensen, P. J. 1977. The history, biology, and taxonomy of the Cytophaga group. Can. J. Microbiol. 23:1599-1653.

6. Felsenstein, J. 1985. Confidence limits on phylogenies: an approach using the bootstrap. Evolution 39:783-791.

7. Gherna, R., and C. R. Woese. 1992. A partial phylogenetic analysis of the "flavobacter-bacteroides" phylum: basis for taxonomic restructuring. Syst. Appl. Microbiol. 15:513-521.

8. Hamana, K., Y. Nakagawa, and K. Yamasato. 1995. Chemotaxonomic significance of polyamine distribution patterns in the Flavobacterium-Cytophaga complex and the related genera. Microbios 81:135-145.

9. Hayes, P. R. 1977. A taxonomic study of flavobacteria and related gram negative yellow pigmented rods. J. Appl. Bacteriol. 43:345-367.

10. Higgins, D. G., A. J. Bleasby, and R. Fuchs. 1992. CLUSTAL V: improved software for multiple sequence alignment. Comput. Applic. Biosci. 8:189191

11. Holt, J. G., N. R. Krieg, P. H. A. Sneath, J. T. Staley, and S. T. Williams (ed.). 1994. Bergey's manual of determinative bacteriology, 9th ed. The Williams \& Wilkins Co., Baltimore, Md.

12. Holt, S. C., and S. A. Kinder. 1989. Genus II. Capnocytophaga, p. 2050-2058 In J. T. Staley, M. P. Bryant, N. Pfennig, and J. G. Holt (ed.), Bergey's manual of systematic bacteriology, vol. 3. The Williams \& Wilkins Co. Baltimore, Md.

13. Kimura, M. 1980. A simple method for estimating evolutionary rates of base substitutions through comparative studies of nucleotide sequences. J. Mol. Evol. 16:111-120.

14. Nakagawa, Y., and K. Yamasato. 1993. Phylogenetic diversity of the genus Cytophaga revealed by $16 \mathrm{~S}$ rRNA sequencing and menaquinone analysis. J. Gen. Microbiol. 139:1155-1161.

15. Nakagawa, Y., and K. Yamasato. 1993. The molecular systematics of Cytophaga species based on the 16S rRNA sequences, p. 163-170. In P. J. Jooste (ed.), Advances in the taxonomy and significance of Flavobacterium, Cytophaga and related bacteria. University Press, University of the Orange Free State, Bloemfontein, South Africa.

16. Nakagawa, Y., and K. Yamasato. 1996. Emendation of the genus Cytophaga and transfer of Cytophaga agarovorans and Cytophaga salmonicolor to Marinilabilia gen. nov.: phylogenetic analysis of the Flavobacterium-Cytophaga complex. Int. J. Syst. Bacteriol. 46:599-603.

17. Oyaizu, H., and K. Komagata. 1981. Chemotaxonomic and phenotypic characterization of the strains of species in the Flavobacterium-Cytophaga complex. J. Gen. Appl. Microbiol. 27:57-107.

18. Paster, B. J., F. E. Dewhirst, I. Olsen, and G. J. Fraser. 1994. Phylogeny of Bacteroides, Prevotella, and Porphyromonas spp. and related genera. J. Bacteriol. 176:725-732.

19. Paster, B. J., W. Ludwig, W. G. Weisburg, E. Stackebrandt, R. B. Hespell, C. M. Hahn, H. Reichenbach, K. O. Stetter, and C. R. Woese. 1985. A phylogenetic grouping of the bacteroides, cytophagas, and certain flavobacteria. Syst. Appl. Microbiol. 6:34-42.

20. Reichenbach, H. 1989. Genus I. Cytophaga, p. 2015-2050. In J. T. Staley, M. P. Bryant, N. Pfennig, and J. G. Holt (ed.), Bergey's manual of systematic bacteriology, vol. 3. The Williams \& Wilkins Co., Baltimore, Md.

21. Reichenbach, H. 1989. Genus Flexibacter, p. 2061-2071. In J. T. Staley, M. P. Bryant, N. Pfennig, and J. G. Holt (ed.), Bergey's manual of systematic bacteriology, vol. 3. The Williams \& Wilkins Co., Baltimore, Md.

22. Reichenbach, H. 1989. Genus Microscilla, p. 2071-2073. In J. T. Staley, M. P. Bryant, N. Pfennig, and J. G. Holt (ed.), Bergey's manual of systematic bacteriology, vol. 3. The Williams \& Wilkins Co., Baltimore, Md.

23. Saitou, N., and M. Nei. 1987. The neighbor-joining method: a new method for reconstructing phylogenetic trees. Mol. Biol. Evol. 4:406-425.

24. Segers, P., W. Mannheim, M. Vancanneyt, K. De Brandt, K.-H. Hinz, K. Kersters, and P. Vandamme. 1993. Riemerella anatipestifer gen. nov., comb. nov., the causative agent of septicemia anserum exsudativa, and its phylogenetic affiliation within the Flavobacterium-Cytophaga rRNA homology group. Int. J. Syst. Bacteriol. 43:768-776.

25. Segers, P., P. Vandamme, P. L. Steyn, W. Mannheim, H. Willekens, M. Bauwens, J. De Ley, and K. Kersters. 1993. Phylogenetic studies of Flavobacterium and related organisms by DNA-rRNA hybridizations, p. 129-136. In P. J. Jooste (ed.), Advances in the taxonomy and significance of Flavobacterium, Cytophaga and related bacteria. University Press, University of the Orange Free State, Bloemfontein, South Africa.

26. Shewan, J. M., and T. A. McMeekin. 1983. Taxonomy (and ecology) of Flavobacterium and related genera. Annu. Rev. Microbiol. 37:233-252.

27. Takeuchi, M., and A. Yokota. 1992. Proposals of Sphingobacterium faecium sp. nov., Sphingobacterium piscium sp. nov., Sphingobacterium heparinum comb. nov., Sphingobacterium thalpophilum comb. nov. and two genospecies of the genus Sphingobacterium, and synonymy of Flavobacterium yabuuchiae and Sphingobacterium spiritivorum. J. Gen. Appl. Microbiol. 38:465-482.

28. Vandamme, P., J.-F. Bernardet, P. Segers, K. Kersters, and B. Holmes. 1994. New perspectives in the classification of the flavobacteria: description of Chryseobacterium gen. nov., Bergeyella gen. nov., and Empedobacter nom. rev. Int. J. Syst. Bacteriol. 44:827-831.

29. Vandamme, P., P. Segers, M. Vancanneyt, K. van Hove, R. Mutters, J. Hommez, F. Dewhirst, B. Paster, K. Kersters, E. Falsen, L. A. Devriese, M. Bisgaard, K.-H. Hinz, and W. Mannheim. 1994. Ornithobacterium rhinotracheale gen. nov., sp. nov., isolated from the avian respiratory tract. Int. J. Syst. Bacteriol. 44:24-37.

30. Weisburg, W. G., Y. Oyaizu, H. Oyaizu, and C. R. Woese. 1985. Natural relationship between bacteroides and flavobacteria. J. Bacteriol. 164:230236.

31. Woese, C. R. 1987. Bacterial evolution. Microbiol. Rev. 51:221-271.

32. Woese, C. R., D. Yang, L. Mandelco, and K. O. Stetter. 1990. The flexibacterflavobacter connection. Syst. Appl. Microbiol. 13:161-165.

33. Yokota, A., M. Akagawa-Matsushita, A. Hiraishi, Y. Katayama, T. Urakami, and K. Yamasato. 1992. Distribution of quinone systems in microorganisms: gram-negative eubacteria. Bull. Jpn. Fed. Culture Collections 8:136-171. 